\title{
ANALISIS KUALITATIF KEPUASAN PASIEN TERHADAP PELAYANAN KESEHATAN GIGI DI POLI KLINIK GIGI DAN MULUT DI RSUD TGK CHIK DITIRO SIGLI
}

\author{
Qualitative Analysis Of Patient Satisfaction With Dental Health Services \\ In Dental And Mouth Clinic Poly At Tgk Chik RSUD Ditiro Sigli \\ Cut Rohana Sofyana ${ }^{1}$, Juliandi Harahap ${ }^{2}$, Umar Zein ${ }^{3}$ \\ ${ }^{1}$ Prodi S2 Kesehatan Masyarakat Institut Kesehatan Helvetia \\ ${ }^{2}$ Fakultas Kedokteran Universitas Sumatera Utara \\ ${ }^{3}$ Fakultas Kesehatan Masyarakat Institut Kesehatan Helvetia \\ Email Penulis Korespondensi: cutrohana78@gmail.com
}

\begin{abstract}
Abstrak
Pada saat ini pelayanan kesehatan gigi perlu mendapatkan perhatian, khususnya masyarakat yang kurang mengerti akan pentingnya menjaga kesehatan gigi. Apabila masalah karies/gigi berlubang dibiarkan dan kecenderungan peningkatannya di masa mendatang tidak dicegah, dampaknya akan sangat merugikan. Penelitian bertujuan untuk memperoleh gambaran kepuasan pasien terhadap pelayanan kesehatan gigi di Poliklinik Gigi dan Mulut di RSUD Tgk. Chik Ditiro Sigli tahun 2020. Desain penelitian menggunakan penelitian kualitatif dengan pendekatan deskriptif. Informan dalam penelitian ini adalah pasien yang berkunjung ke Poliklinik Gigi dan Mulut RSUD Tgk Chik Ditiro Sigli sebanyak 6 orang yang terdiri dari pasien umum sebanyak 2 orang, pasien BPJS/ASKES sebanyak 2 orang dan pasien inhealth sebanyak 2 orang. Teknik analisis data dengan reduksi data, penyajian data, dan penarikan kesimpulan. Hasil penelitian menunjukkan bahwa dari 6 informan rata-rata jawaban mereka adalah : Berdasarkan kehandalan belum puas karena proses penerimaan pasien masih sulit dan pelayanan tenaga kesehatan tidak maksimal.Berdasarkan daya tanggap belum puas karena perawat tidak memberikan penjelasan informasi secara maksimal dan tidak segera datang ketika di butuhkan, berdasarkan jaminan puas karena dokter mampu memberikan jaminan kesembuhan pada pasien. berdasarkan empati belum puas tenaga kesehatan tidak memberikan perhatian pada pasien dan tidak menjelaskan informasi terkait pelayanan kesehatan gigi serta tidak menjelaskan prosedur pemeriksaan, berdasarkan tampilan fisik belum puas ruangan poliklinik gigi dan mulut terlalu kecil dan tidak nyaman serta kurang terjaga privasinya. Kesimpulan yang didapat dari hasil penelitian ini yaitu selain dimensi jaminan informan belum puas terhadap pelayanan yang berkunjung ke Poliklinik Gigi dan Mulut RSUD Tgk Chik Ditiro Sigli. Diharapkan kepada rumah sakit agar dapat mempertahankan kepuasan pasien dengan meningkatkan lagi mutu pelayanan kesehatan gigi dan mulut dengan memperhatikan berbagai dimensi, yaitu dimensi kehandalan, daya tanggap, jaminan, empati dan tampilan fisik.
\end{abstract}

\section{Kata Kunci : Kepuasaan, Kehandalan, Daya Tanggap, Jaminan, Empati Dan Tampilan Fisik.}

\begin{abstract}
Currently, dental health services need attention, especially people who do not understand how to maintain dental health. If the caries / cavities problem is left unchecked and the trend of its future increase is not prevented, the impact will be very detrimental. This study aims to obtain a description of patient satisfaction with dental health services at the Dental and Oral Polyclinic at Tgk. Chik Ditiro Sigli in 2020. The research design used a qualitative descriptive approach. The informants in this study were 6 patients who visited the Dental and Oral Polyclinic of Tgk Chik Ditiro Sigli Hospital, consisting of 2 general patients, 2 BPJS / ASKES patients and 2 inhealth patients. Data analysis techniques with data reduction, data presentation, and data collection. The results showed that of the 6 informants their average answers were: Based on the reliability, they were not satisfied because the process of receiving patients was still difficult and the service of health workers was not optimal. based on the guarantee of satisfaction because the doctor is able to guarantee a cure for the patient. Based on the dissatisfied empathy, the
\end{abstract}


Journal of Healthcare Technology and Medicine Vol. 6 No. 2 Oktober 2020

Universitas Ubudiyah Indonesia

e-ISSN : 2615-109X

health workers do not pay attention to the patient and do not explain information related to dental health and do not explain the examination procedure, based on the appearance of dissatisfaction, the dental and mouth polyclinic room is too small and uncomfortable and lacks privacy. The conclusion obtained from the results of this study is that in addition to the dimensions of assurance, the informants were not satisfied with the services that visited the Dental and Oral Polyclinic of Tgk Chik Ditiro Sigli Hospital. It is hoped that the hospital can maintain patient satisfaction by improving the quality of dental and oral health services by paying attention to various dimensions, namely the dimensions of reliability, responsiveness, assurance, empathy and physical appearance.

Keywords: Patient Satisfaction, Reliability, Responsiveness, Assurance, Empathy and Physical Appearance.

\section{PENDAHULUAN}

Pelayanan kesehatan gigi dilakukan untuk memelihara dan meningkatkan derajat kesehatan masyarakat dalam bentuk peningkatan kesehatan gigi, pencegahan penyakit gigi, pengobatan penyakit gigi dan pemulihan kesehatan gigi yang dilakukan secara terpadu, terintegrasi dan berkesinambungan dan dilaksanakan melalui pelayanan kesehatan gigi perseorangan, pelayanan kesehatan gigi masyarakat, usaha kesehatan gigi sekolah, serta pemerintah dan pemerintah daerah wajib menjamin ketersediaan tenaga, fasilitas pelayanan, alat dan obat kesehatan gigi dan mulut dalam rangka memberikan pelayanan kesehatan gigi dan mulut yang aman, bermutu, dan terjangkau oleh masyarakat [1].

World Health Organization (WHO), Foreign Direct Investment (FDI), International Asociation For Dental Research (IADR) untuk mengurangi kehilangan gigi akibat penyakit priodontal terutama untuk kasus kebersihan mulut yang buruk [2]. Hasil Riset kesehatan dasar (Riskesdas) tahun 2014 menunjukkan sebesar 25,9\% penduduk Indonesia mempunyai masalah gigi [3].

Banyak faktor yang menyebabkan tingginya masalah kesehatan gigi yang dapat mempengaruhi kesehatan umum. Pola hidup tidak sehat, dan tidak memeriksakan gigi secara teratur, serta faktor-faktor lain seperti diet, merokok, kurang vitamin dapat menyebabkan masalah pada kesehatan gigi. Air yang kurang mengandung flour, jauhnya jarak untuk akses pelayanan kesehatan gigi, dan kurangnya pengetahuan orang tua dalam mendidik anak juga dapat menyebabkan sakit gigi [4].

Dengan demikian pelayanan kesehatan gigi yang diberikan kepada pasien sangat berkaitan erat dengan tingkat kepuasan pasien yang telah menerima perawatan dari tenaga kesehatan. Pelayanan kesehatan gigi merupakan pelayanan profesional yang diberikan oleh dokter gigi dan perawat gigi kepada perorangan atau masyarakat dibidang promotif, preventif dan kuratif yang ditujukan untuk meningkatkan derajat kesehatan gigi yang optimal [5].

Salah satu pusat pelayanan kesehatan di Kota Sigli Kabupaten Pidie Provinsi Aceh adalah Rumah Sakit Umum Daerah Tgk. Chik di Tiro. Berdasarkan jenis pelayanan rumah sakit ini adalah rumah sakit umum yang dimiliki oleh Pemerintah Kabupaten Pidie, RSUD Tgk. Chik Di Tiro ini merupakan rumah sakit kelas $\mathrm{B}[6]$. 
Journal of Healthcare Technology and Medicine Vol. 6 No. 2 Oktober 2020

Universitas Ubudiyah Indonesia

e-ISSN : 2615-109X

Berdasarkan data dari Poliklinik Gigi dan Mulut RSUD Tgk. Chik Ditiro Sigli Provinsi Aceh diketahui bahwa jumah kunjungan rawat jalan RSUD Tgk. Chik Ditiro Sigli pada poliklinik gigi dan mulut mengalami fluktuasi. Pada tahun 2015 jumlah kunjungan pada poliklinik gigi dan mulut sebanyak 6604 kunjungan, dimana kunjungan baru sebanyak 1609 kunjungan dan kunjungan lama sebanyak 4995 kunjungan. Pada tahun 2016 mengalami peningkatan jumlah kunjungan pasien yaitu sebanyak 7317 kunjungan, dimana kunjungan baru sebanyak 1407 kunjungan dan kunjungan lama sebanyak 5910 kunjungan. Pada tahun 2017 mengalami penurunan jumlah total kunjungan pasien yaitu sebanyak 6600 kunjungan, dimana kunjungan baru sebanyak 1325 kunjungan dan kunjungan lama sebanyak 5275 kunjungan. Pada tahun 2018 mengalami penurunan jumlah total kunjungan pasien yaitu sebanyak 5500 kunjungan, dimana kunjungan baru sebanyak 1734 kunjungan dan kunjungan lama sebanyak 3766 kunjungan dan pada tahun 2019 mengalami penurunan drastis akibat pemindahan lokasi poliklinik gigi dan mulut ke bagian belakang rumah sakit yang membuat jarak tempus semakin jauh, jumlah total kunjungan pasien yaitu sebanyak 4100 kunjungan, dimana kunjungan baru sebanyak 1011 kunjungan dan kunjungan lama sebanyak 3088 kunjungan.

Penurunan kunjungan pasien yang terjadi disebabkan karena ketidapuasan pasien terhadap pelayanan. Hal ini diperkuat dari hasil angket kepuasan pasien yang dibagikan pihak Poliklinik Gigi dan Mulut RSUD Tgk. Chik Ditiro Sigli Provinsi Aceh kepada setiap pasien yang berkunjung ke Poliklinik Gigi dan Mulut RSUD Tgk. Chik Ditiro Sigli Provinsi Aceh diperoleh bahwa sebagian besar $(65,8 \%)$ menyatakan tidak puas dengan pelayanan yang diberikan petugas kesehatan. Alasan pasien tidak puas disebabkan karena pelayanan di Poliklinik Gigi dan Mulut belum optimal, pasien terlalu lama menunggu, perawat datang terlambat, dokter gigi kurang terampil memberikan pelayanan kesehatan gigi, dokter gigi kurang mampu menjelaskan keadaan yang dialami pasien, dokter gigi kurang tanggap atas keluhan pasien, perawat kurang cepat menerima pasien, perawat kurang ramah dalam melayani pasien.

Ketidakpuasan pasien yang terjadi karena perbandingan antara persepsinya terhadap pelayanan yang diterima dengan harapannya sebelum mendapatkan pelayanan. Apabila harapannya terpenuhi, berarti pelayanan tersebut telah memberikan suatu mutu yang luar biasa dan juga akan menimbulkan kepuasan yang tinggi. Sebaliknya apabila harapannya itu tidak tercapai, maka diartikan mutu pelayanan tersebut tidak memenuhi apa yang diharapkannya.

Berdasarkan data dari Poliklinik Gigi dan Mulut RSUD Tgk. Chik Ditiro Sigli diperoleh bahwa jenis pelayanan yang dilakukan di Poliklinik Gigi dan Mulut adalah : 1) pedodonti yaitu perawatan gigi yang menangani masalah pertumbuhan dan perkembangan pada gigi dan mulut pasien anak, 2) konservasi yaitu perawatan gigi yang menangani perawatan restorasi gigi (misalnya tambalan gigi, pembuatan mahkota buatan, perawatan saluran akar) tiap-tiap gigi, 3) periodonti yaituperawatan gigi yang menangani pasien 
Journal of Healthcare Technology and Medicine Vol. 6 No. 2 Oktober 2020

Universitas Ubudiyah Indonesia

e-ISSN : 2615-109X

dengan perawatan jaringan penyangga gigi, termasuk diantaranya gusi, tulang rahang dan 4) pencabutan 5) Prosthodonti yaitu perawatan gigi yang menangani pergantian gigi 1 atau lebih.

Berdasarkan survei awal yang dilakukan di Poliklinik Gigi dan Mulut RSUD Tgk. Chik Ditiro Sigli di peroleh bahwa pelayanan kesehatan gigi masih kurang baik, dimana dari segi kualitas dokter gigi dan perawat gigi belum mampu dengan teliti memberikan pelayanan kesehatan gigi. Perawat kurang bertanggung jawab penuh selama jam kerja terhadap asuhan keperawatan pasien mulai dari pasien masuk sampai keluar. Dari segi ketepatan waktu yaitu waktu kerja yang efektif atau ketepatan waktu dalam menyelesaikan tugas kurang, dimana datang terlambat dan pulang ingin cepat, para pasien menilai bahwa kecepatan dokter gigi dan perawat gigi membantu masih sangat kurang, perawat masih agak lambat dalam menangani pasien. Keramahan dokter gigi dan perawat gigi masih kurang membantu dalam proses komunikasi penjelasan tindakan pelayanan dokter gigi dan perawat gigi belum memuaskan.

Fenomena tentang pelayanan kesehatan gigi yang terjadi adalah masih banyak keluhan dari pasien maupun keluarga pasien atas pelayanan dokter gigi dan perawat gigi. Dapat dilihat bahwa kecepatan dalam membantu masih kurang, dokter gigi agak lambat menangani pasien, hal ini tentu akan mengganggu hasil pencapaian pelayanan kesehatan gigi tersebut. Apabila hal ini kurang mendapat perhatian dan dibiarkan tanpa upaya penanganan secara tepat dikhawatirkan akan berdampak terhadap peningkatan kualitas sumber daya tenaga kesehatan, khususnya dalam pemberian pelayanan kesehatan gigi di Poliklinik Gigi dan Mulut RSUD Tgk. Chik Ditiro Sigli.

Kemudian berdasarkan hasil wawancara terhadap 10 orang pasien diperoleh bahwa 6 orang pasien mengatakan kurang puas atas pelayanan dokter gigi dan perawat gigi dan 4 orang pasien mengatakan sudah puas atas pelayanan dokter gigi dan perawat gigi. Kepuasan pasien ini terkait dengan mutu pelayanan kesehatan gigi yang diberikan oleh dokter gigi dan perawat gigi, dimana harapan pasienterpenuhi artinya pelayanan telahmemberikan suatu mutu yang luar biasa yang menimbulkan kepuasan pasien.

Dari 6 orang pasien yang mengatakan kurang puas atas pelayanan dokter gigi dan perawat gigi terdiri dari 4 orang tidak puas terjadi karena pasien merasa prosedur pelayanan penerimaan yang berbelit-belit di Poliklinik Gigi dan Mulut, dokter gigi memperlihatkan kurang terampil memberikan pelayanan kesehatan gigi, merasa bahwa dokter gigi kurang mampu bertindak dan menangani pasien masalah pasien dengan baik, dokter gigi memperlihatkan tergesa-gesa dan kurang teliti dalam melakukan pemeriksaan kondisi pasien, dokter gigi tidak menjelaskan kondisi gigi dan mulut yang dialami pasien dengan baik. Kemudian 2 orang pasien yang tidak puas mengatakan disebabkan karena dokter gigi sebantar saja melakukan pemeriksaan jadi tanggapan pasien kurang bagus dalam pemeriksaan, pasien mengatakan seolah-olah dokter gigi hanya asal melihat kondisi pasien saja sehingga menimbulkan rasa keragu-raguan pasien akan kesembuhan dan hasil pemeriksaan, perawat yang mendampingi dokter kurang ramah. 
Journal of Healthcare Technology and Medicine Vol. 6 No. 2 Oktober 2020

Universitas Ubudiyah Indonesia

e-ISSN : 2615-109X

Kemudian 4 orang pasien mengatakan puas karena merasa pelayanan yang didapatkannya sudah memenuhi harapannya yaitu dokter ramah menyapa pasien, dokter selain memeriksa tetap menjelaskan masalah yang dihadapi pasien, perawat yang mendampingi dokter gigi ramah dan tanggap saat mendampingidokter saat pemeriksaan dan pasien merasa lega karena setelah pemeriksaan langsung memperoleh diagnosa yang jelas dan pasien merasa bahwa perawat sangat membantu dalam menjalani pengobatan baik dari segi administrasi dan pelayanan kesehatan yang diberikan.

Fenomena ini tidak akan terjadi jika dokter gigi memberikan pelayanan sesuai dengan kompetensi dokter gigi Indonesia dan standar operasional pelayanan. Kompetensi tersebut meliputi profesionalisme yaitu melakukan praktik di bidang kedokteran gigi sesuai dengan keahlian, tanggung jawab, kesejawatan, etika dan hukum yang berlaku, penguasaan ilmu pengetahuan kedokteran dan kedokteran gigi yaitu memahami ilmu kedokteran dasar, ilmu kedokteran klinik yang relevan, ilmu kedokteran gigi dasar, ilmu kedokteran gigi terapan dan ilmu kedokteran gigi klinik sebagai dasar profesionalisme serta pengembangan ilmu kedokteran gigi, pemeriksaan fisik secara umum dan sistem stomatognatik yaitu melakukan pemeriksaan, mendiagnosis dan menyusun rencana perawatan untuk mencapai kesehatan gigi mulut yang prima melalui tindakan promotif, preventif, kuratif dan rehabilitatif, pemulihan fungsi sistem stomatognatik yaitu melakukan tindakan pemulihan fungsi sistem stomatognatik melalui penatalaksanaan klinik, kesehatan gigi mulut masyarakat yaitu menyelenggarakan upaya kesehatan masyarakat menuju kesehatan gigi mulut yang prima, manajemen praktik kedokteran gigi yaitu menerapkan fungsi manajemen dalam menjalankan praktik kedokteran gigi [7].

Standar operasional prosedur (SOP) pelayanan di poli gigi adalah pasien datang dari loket pendaftaran dengan membawa kartu berobat menuju poli gigi, petugas di poli gigi memanggil pasien untuk masuk ke poli gigi sesuai nomor urut., petugas mencocokkan identitas pasien dengan kartu rawat jalan, dokter gigi menganamnesa pasien dan melakukan pemeriksaan terhadap pasien (secara umum, lokal), petugas/dokter melakukan pemeriksaan penunjang (TD, KGD) sesuai indikasi, dokter gigi menegakkan diagnosa, petugas gigi memberikan form Persetujuan Tindakan kepada pasien/ keluarga pasien untuk ditanda tangani, petugas gigi menyiapkan peralatan pemeriksaan gigi dan melakukan tindakan(pencabutan atau penambalan) berdasarkan hasil diagnosa dan dokter gigi memberikan resep bagi pasien yang memerlukan.

\section{METODE}

Jenis penelitian ini menggunakan metode kualitatif dengan pendekatan deskriptifuntuk memperoleh jawaban atau informasi yang mendalam tentang pendapat dan perasaan seseorang yang memungkinkan untuk mendapatkan hal-hal yang tersirat tentang sikap, kepercayaan, motivassi dan perilaku individu. Penelitian ini dilakukan di Poliklinik Gigi dan Mulut RSUD Tgk Chik Ditiro Sigli. Penelitian ini dilakukan 
Journal of Healthcare Technology and Medicine Vol. 6 No. 2 Oktober 2020

Universitas Ubudiyah Indonesia

e-ISSN : 2615-109X

mulai bulan Desember 2020. Populasi pada penelitian ini sebanyak 6 orang yang terdiri dari pasien umum sebanyak 2 orang, pasien BPJS/ASKES sebanyak 2 orang, pasien in health sebanyak 2 orang dan informan tambahan adalah petugas Poliklinik Gigi dan Mulut RSUD Tgk Chik Ditiro Sigli sebanyak 2 orang yaitu 1 orang dokter gigi dan 1 orang perawat.

\section{HASIL}

Karakteristik Responden

Karakteristik sampel yang diambil dalam penelitian ini mencakup pendidikan, pekerjaan, jaminan kesehatan dan tempat tinggal.

Tabel 1, Karakteristik Responden

\begin{tabular}{clcc}
\hline No & Karakteristik Informan & Keterangan & Jumlah \\
\hline 1 & Pendidikan & SD & 1 \\
& & SMP & 1 \\
& & SMA & 2 \\
& & DIII & 1 \\
\hline 2 & Pekerjaan & SI & 1 \\
& & PNS & 1 \\
& & Ibu Rumah Tangga & 3 \\
\hline 3 & Jaminan Kesehatan & Petani & 2 \\
\hline & & BPJS/ASKES & 2 \\
& & Umum & 2 \\
\hline 4 & Tempat Tinggal & In health & 2 \\
& & Pidie & 1 \\
& & Caleue & 1 \\
& & Bambi & 1 \\
& & Keutapang & 1 \\
& & Garot & 1 \\
\end{tabular}

\section{a. Kehandalan}

Kepuasan pasien pengguna layanan BPJS/ASKES, Layanan umum, dan in health terhadap kehandalan dalam pelayanan kesehatan gigi dapat di simpulkan bahwa pelayanan yang dirasakan tidak puas di karenakan masalah antrian dan dokterpun melakukan pekerjaan terburu-buru sehingga tahap pemeriksaanpun tidak dilakukan dengan baik.

\section{b. Daya Tanggap}

Kepuasan pasienpengguna layanan BPJS/ASKES, Layanan Umum dan In Health terhadap daya tanggap dalam pelayanan kesehatan gigi pada informan merasakan tidak puas dikarenakan petugas kesehatan tidak memberikan penjelasan dan pemahaman dengan baik kepada pasien dikarenakan kesiapan dari perawat yang kurang sehingga perawat menunda memberikan bantuan ketika pasien membutuhkan. Sehingga pasien lebih memilih dokter untuk menyampaikan keluhan dan keperluan lain, karena informan menganggap dokter lebih tanggap terhadap masalah informan dari pada perawat. 
Journal of Healthcare Technology and Medicine Vol. 6 No. 2 Oktober 2020

Universitas Ubudiyah Indonesia

e-ISSN : 2615-109X

\section{c. Jaminan}

Kepuasan pasienpengguna layanan BPJS/ASKES, Layanan Umum dan In Health terhadap jaminan dalam pelayanan kesehatan gigi diketahui bahwa informan mengatakan merasa puas terhadap pelayanan yang didapatkan daninforman merasakan dokter mampu meyakinkan kesembuhan pasien sehingga informan tidak khawatir dengan keluhan yang di alami. Dokter juga memberikan keamanan dan kerahasiaan (privasi) terhadap informan.

\section{d. Empati}

Kepuasan pasien pengguna layanan BPJS/ASKES, Layanan Umum dan In Health terhadap empati dalam pelayanan kesehatan gigi menjelaskan bahwa informan sangat puas dengan pelayanan yang diterima. Namun masih ada informan yang tidak puas dikarenakan dokter ketika melayani tidak sabar, tindakan yang dilakukan terburu-buru. Hal ini mungkin di karenakan banyak pasien yang menunggu sehingga dokter juga tidak memberikan informasi sebelum pemeriksaan.

\section{e. Tampilan Fisik}

Kepuasan pasien pengguna layanan BPJS/ASKES, Layanan Umum dan In Health terhadap tampilan fisik dalam pelayanan kesehatan gigi kurang puas, informan mengatakan bahwa kurang kenyamanan karena ruangan terlalu kecil dan berisik sehingga ketenangan tidak ada. Suara kebisingan itu di sebabkan karena ruang tunggu terlalu dekat dengan ruangan pemeriksaan. Selain itu kurang privasi karena hanya di batasi oleh tirai tipis. Untuk alat medis di rumah sakit sudah lengkap dan berfungsi secara baik. Dilihat dari segi penampilan tenaga kesehatan sudah rapi dan bersih.

\section{PEMBAHASAN}

\section{Kepuasan pasien Terhadap Kehandalan}

Hasil penelitian yang dilakukan peneliti berdasarkan dimensi kehandalan tidak memuaskan. Dari hasil wawancara yang dilakukan peneliti banyak pasien pengguna layanan BPJS/ASKES, Layanan umum, dan in health mengatakan bahwa pelayanan yang dirasakan tidak puas di karenakan masalah antrian dan dokter pun melakukan pekerjaan terburu-buru sehingga tahap pemeriksaan pun tidak dilakukan dengan baik. Kesimpulan hasil wawancara informan 1 Layanan BPJS/ASKES sebagai berikut:

\section{"Banyaknya pasien menimbulkan antrian sehingga dokter bekerja terburu-buru dan tahap pemeriksa pun tidak dilakukan".}

Begitu juga kesimpulan hasil wawancara informan 2 layanan BPJS/ASKES:

"Jumlah pasien yang banyak menyebabkan antrian lama dan dokter jadi buru-buru melakukan pemeriksaan dan tindakan".

Hasil Kesimpulan informan 3 Layanan Umum 
Journal of Healthcare Technology and Medicine Vol. 6 No. 2 Oktober 2020

Universitas Ubudiyah Indonesia

e-ISSN : 2615-109X

"Jumlah pasien yang banyak menyebabkan antrian lama dan dokter jadi buru-buru melakukan pemeriksaan dan tindakan, informasi yang di berikan jadi tidak jelas”.

Hal serupa juga di sampaikan oleh informan 4 Layanan Umum sebagai berikut:

"Jumlah pasien yang banyak menyebabkan antrian lama dan dokter melakukan pemeriksaan tidak secara bertahap".

Hasil kesimpulan yang sama juga disampakan oleh informan 5 Layanan In Health

"Jumlah pasien yang banyak menyebabkan antrian lama dan dokter melakukan pemeriksaan tidak secara bertahap".

Hal serupa di sampaikan oleh informan 6 Layanan In Health

"Jumlah pasien yang banyak menyebabkan antrian lama dan dokter melakukan pemeriksaan tidak secara bertahap”.

Hasil penelitian ini sesuai dengan penelitian yang dilakukan oleh Menti Youlanda [8] Waktu tunggu yang relatif lama biasanya dikarenakan prosedur pendaftaran pasien BPJS yang memang butuh menyiapkan berkas persyaratan yang lengkap dan bergantung pada sistem online jaringan internet dan server BPJS. Pasien yang menunggu lama untuk mendapatkan pelayanan secara tidak langsung akan berdampak pada kepuasan pasien terhadap pelayanan yang diberikan. Tidak sedikit masih dijumpai adanya keluhan dari beberapa pasien karena masalah waktu menunggu di poliklinik yang berharap mendapatkan pelayanan kesehatan secepatnya, sehingga kondisi antrian terlihat begitu padat, dan pasien terlihat bosan dan gelisah karena mengingat adanya keterbatasan waktu selama pelayanan kesehatan, sehingga masih dijumpai beberapa pasien yang menanyakan kembali ke petugas pendaftaran maupun petugas poliklinik terkait pelayanan kesehatan.

Kepuasan pasien dapat dilihat dari berbagai dimensi, salah satunya dimensi keandalan (reability) yaitu dimensi yang mengukur keandalan suatu pelayanan jasa kepada konsumen. Keandalan di defenisikan sebagai kemampuan untuk memberikan pelayanan sesuai dengan yang di janjikan secara akuran dan terpercaya [9].

Di dalam penelitian ini faktor reliability (kehandalan) berhubungan dengan tingkat kepuasan pasien dan digunakan para pelanggan dalam mengevaluasi mutu pelayanan kesehatan. Apabila suatu pelayanan kesehatan kurang handal atau tidak dapat di percaya maka pasien tersebut merasa kurang puas atau tidak puas [10].

\section{Kepuasan Pasien Terhadap Daya Tanggap}

Kurangnya kepuasan pasien pengguna layanan BPJS/ASKES, Layanan Umum dan In health terhadap daya tanggap dalam pelayanan kesehatan gigi dikarenakan petugas kesehatan tidak memberikan penjelasan dan pemahaman dengan baik kepada pasien dikarenakan kesiapan dari perawat yang kurang sehingga perawat menunda memberikan bantuan ketika pasien membutuhkan. Sehingga pasien lebih memilih dokter untuk menyampaikan keluhan dan keperluan lain, karena informan menganggap dokter 
Journal of Healthcare Technology and Medicine Vol. 6 No. 2 Oktober 2020

Universitas Ubudiyah Indonesia

e-ISSN : 2615-109X

lebih tanggap terhadap masalah informan dari pada perawat. Kesimpulan hasil wawancara informan 1 BPJS/ASKES sebagai berikut:

"Perawat tidak memberikan penjelasan dan pelayanan dengan baik karena kesiapan perawat lambat sehingga perawat menunda untuk memberikan bantuan kepada pasien”.

Hal serupa juga di sampaikan oleh informan 2 BPJS/ASKES

"Perawat tidak memberikan penjelasan dengan baik karena kesiapan perawat kurang sehingga perawat menunda untuk memberikan bantuan kepada pasien”.

Kesimpulan hasil wawancara informan 3 layanan umum sebagai berikut:

“Pasien tidak memahami penjelasan perawat karena kesiapan perawat tidak baik sehingga perawat menunda untuk memberikan bantuan kepada pasien”.

Hal yang berbedan di sampaikan oleh informan 4 layanan umum.

"Perawat dan dokter tidak memberikan pemahaman yang baik kepada pasien dikarenakan perawat kurang persiapan dalam pelayanan".

Kesimpulan hasil wawancara informan 5 In Health

"Perawat tidak memberikan pemahaman dengan baik karena kesiapan perawat kurang sehingga perawat menunda untuk memberikan bantuan kepada pasien".

Hal serupa yang disampaikan oleh informan 6 In Health

"Perawat tidak memberikan penjelasan dengan baik karena kesiapan perawat kurang sehingga perawat menunda untuk memberikan bantuan kepada pasien".

Hasil penelitian diatas sesuai dengan penelitian yang dilakukan oleh Khairun Nisa, dkk [11] terdapat hubungan kualitas pelayanan kesehatan dimensi daya tanggap terhadap kepuasan pasien, dimana hasil uji bivariat dengan uji chi square menunjukkan hubungan yang signifikan dengan $p$ value $=0,001$. Daya tanggap dari petugas rumah sakit dalam memberikan pelayanan kesehatan akan meningkatkan kepuasan pasien.

Daya tanggap atau Ketanggapan (responsiveness) adalah kemampuan untuk membantu konsumen dan memberikan pelayanan dengan cepat kepada konsumen. Dimensi ketanggapan merupakan dimensi yang bersifat paling dinamis. Hal ini di pengaruhi oleh faktor perkembangan teknologi. Salah satu contoh aspek ketanggapan dalam pelayanan adalah kecepatan [9].

Daya tanggap juga merupakan pemberian pelayanan kepada pasien dengan cepat dan tanggap baik dalam pelayanan maupun pemeriksaan. Tanggap berarti ada di tempat, bisa dihubungi dan rela menolong pasien setiap kali mereka menghadapi masalah. Tangap juga berarti senantiasa memberikan informasi yang cukup dan menyediakan pelayanan secepat mungkin, dengan demikian seluruh tenaga kesehatan selalu ada di saat pasien membutuhkan. Mutu yang baik berkaitan dengan kecepatan pelayanan, sebaliknya pasien akan menganggap pelayanan kesehatan jelek apabila antri lama meskipun dia professional [12]. 
Journal of Healthcare Technology and Medicine Vol. 6 No. 2 Oktober 2020

Universitas Ubudiyah Indonesia

e-ISSN : 2615-109X

\section{Kepuasan Pasien Terhadap Jaminan}

Kepuasan pasien pengguna layanan BPJS/ASKES, Layanan Umum dan In Health terhadap jaminan dalam pelayanan kesehatan gigi diketahui bahwa informan mengatakan merasa puas terhadap pelayanan yang didapatkan dan informan merasakan dokter mampu meyakinkan kesembuhan pasien sehingga informan tidak khawatir dengan keluhan yang di alami. Dokter juga memberikan keamanan dan kerahasiaan (privasi) terhadap informan. Kesimpulan hasil wawancara informan 1 layanan BPJS/ASKES sebagai berikut:

"Dokter memberikan keyakinan dengan baik dan usaha yang maksimal juga menjaga privasi pasien di saat memberikan pelayanan".

Hal serupa juga di sampaikan oleh informan 2 layanan BPJS/ASKES

"Dokter memberikan keyakinan dengan baik dan usaha yang maksimal juga menjaga privasi pasien ketika memberikan pelayanan”.

Kesimpulan hasil wawancara informan 3 layanan umum sebagai berikut

"Dokter memberikan keyakinan dengan baik dan usaha yang maksimal juga menjaga privasi pasien di saat memberikan pelayanan".

Hal serupa juga disampaikan oleh informan 4 layanan umum

"Dokter memberikan keyakinan dengan baik dan usaha yang maksimal juga menjaga privasi pasien di saat memberikan pelayanan".

Kesimpulan hasil wawancara informan 5 layanan In Health adalah sebagai berikut"

"Dokter memberikan keyakinan dengan baik dan usaha yang maksimal juga menjaga privasi pasien di saat memberikan pelayanan".

Hal serupa juga di sampaikan oleh informan 6 layanan In Health

"Dokter memberikan keyakinan dengan baik dan usaha yang maksimal juga menjaga privasi pasien di saat memberikan pelayanan”.

Accurance yaitu kemampuan petugas kesehatan untuk menimbulkan keyakinan dan kepercayaan terhadap janji yang telah dikemukakan kepada konsumen, dan hal tersebut berhubungan dengan tingkat kepuasan pasien. Demi meningkatkan kualitas pelayanan dan menjaga keselamatan pasien dalam menerapkan keselamatan pasien sehingga pasien yang masuk akan merasakan aman [13].

Jaminan dan kepastian adalah pengetahuan, kesopansantunan, dan kemampuan para pegawai perusahaan untuk menumbuhkan rasa percaya para pelanggan (pasien) kepada perusahaan (Rumah Sakit). Hal ini meliputi beberapa konsumen antara lain komunikasi, kredibilitas, keamanan, kompetensi, dan sopan santun. Dimensi jaminan mencakup pengetahuan, kemampuan, kesopanan dan sifat dapat di percaya keryawan terhadap konsumen. Nilai yang terhantar akan membentuk loyalitas pelanggan. Hasil penelitian lain menyimpulkan dimensi jaminan mempunyai hubungan dan pengaruh terhadap loyalitas [14].

\section{Kepuasan Pasien Terhadap Empati}


Journal of Healthcare Technology and Medicine Vol. 6 No. 2 Oktober 2020

Universitas Ubudiyah Indonesia

e-ISSN : 2615-109X

Kepuasan pasien pengguna layanan BPJS/ASKES, Layanan Umum dan In Health terhadap empati dalam pelayanan kesehatan gigi menjelaskan bahwa informan sangat puas dengan pelayanan yang diterima. Namun masih ada informan yang tidak puas dikarenakan dokter ketika melayani tidak sabar, tindakan yang dilakukan terburu-buru. Hal ini mungkin di karenakan banyak pasien yang menunggu sehingga dokter juga tidak memberikan informasi sebelum pemeriksaan. Kesimpulan hasil wawancara informan 1 layanan BPJS/ASKES sebagai berikut:

"Dokter peduli terhadap pasien dengan memberikan perhatian dan kesabaran dengan baik kepada pasien saat memberikan pelayanan”.

Hal serupa juga di sampaikan oleh informan 2 layanan BPJS/ASKES

"Dokter peduli terhadap pasien dengan memberikan perhatian dan kesabaran dengan baik kepada pasien saat memberikan pelayanan".

Hasil kesimpulan wawancara dari informan 3 Layanan umum sebagai berikut:

"Dokter peduli terhadap pasien dengan memberikan perhatian dan kesabaran dengan baik kepada pasien saat memberikan pelayanan”.

Hal serupa juga di sampaikan oleh informan 4 layanan umum

"Dokter peduli terhadap pasien dengan memberikan perhatian dan kesabaran dengan baik kepada pasien saat memberikan pelayanan”.

Kesimpulan hasil wawancara informan 5 layanan In Health

"Dokter peduli terhadap pasien dengan memberikan perhatian dan kesabaran dengan baik kepada pasien saat memberikan pelayanan”.

Hal serupa juga di sampaikan oleh informan 6 layanan In Health

"Dokter peduli terhadap pasien dengan memberikan perhatian namun dokter tidak memiliki kesabaran ketika memberikan pelayanannya”.

Hasil penelitian ini sejalan dengan penelitian yang dilakukan oleh Sarah Ladytami [15] berarti bahwa emphaty berpengaruh signifikan terhadap satisfaction, hal ini dapat diartikan bahwa kualitas pelayanan kesehatan gigi dan mulut atas Aspek perhatian (Emphaty), selama ini telah memberikan layanan yang berkualitas dimana semakin tinggi kualitas layanan kepada pasien atas Aspek empati. Dimensi empati merupakan kemudahan dalam melakukan hubungan komunikasi yang baik, perhatian pribadi dan memahami kebutuhan pasien sebagai pelanggan dan bertindak demi kepentingan pasien.

Dalam hal ini empati sangat penting bagi pasien, karena perhatian merupakan prioritas bagi pasien. Dimensi empati mencakup hubungan komunikasi, perhatian dan pemahaman kebutuhan konsumen. Jika konsumen merasa bahwa tenaga kesehatan dapat memberikan empati kepada pasien maka mereka tidak lagi merasa ragu untuk tetap menggunakan jasa yang di berikan. Hal ini akan membentuk loyalitas pasien. Sehingga dapat di katakan bahwa terdapat hubungan yang searah antara dimensi empati terhadap loyalitas pasien. 
Journal of Healthcare Technology and Medicine Vol. 6 No. 2 Oktober 2020

Universitas Ubudiyah Indonesia

e-ISSN : 2615-109X

\section{Kepuasan Pasien Terhadap Tampilan Fisik}

Kepuasan pasien pengguna layanan BPJS/ASKES, Layanan Umum dan In Health terhadap tampilan fisik dalam pelayanan kesehatan gigi kurang puas, informan mengatakan bahwa kurang kenyamanan karena ruangan terlalu kecil dan berisik sehingga ketenangan tidak ada. Suara kebisingan itu di sebabkan karena ruang tunggu terlalu dekat dengan ruangan pemeriksaan. Selain itu kurang privasi karena hanya di batasi oleh tirai tipis. Untuk alat medis di rumah sakit sudah lengkap dan berfungsi secara baik. Dilihat dari segi penampilan tenaga kesehatan sudah rapi dan bersih. Kesimpulan hasil wawancara informan 1 Layanan BPJS/ASKES sebagai berikut:

"Ruangan poliklinik gigi dan mulut yang kecil membuat tidak nyaman karena ruang tunggu pasien dekat dengan ruang pemeriksaan".

Hal serupa juga di sampaikan oleh informan 2 layanan BPJS/ASKES

"Ruangan poliklinik gigi dan mulut yang kecil membuat tidak nyaman karena ruang tunggu pasien dekat dengan ruang pemeriksaan".

Kesimpulan hasil wawancara informan 3 layanan umum adalah sebagai berikut:

"Ruangan poliklinik gigi dan mulut yang kecil membuat tidak nyaman karena ruang tunggu pasien dekat dengan ruang pemeriksaan dan kurang privasi karena hanya di batasi oleh tirai".

Hal serupa juga disampaikan oleh informan 4 layanan umum

"Ruangan poliklinik gigi dan mulut yang kecil membuat tidak nyaman karena ruang tunggu pasien dekat dengan ruang pemeriksaan dan kurang privasi karena hanya di batasi oleh tirai”.

Kesimpulan hasil wawancara informan 5 layanan In Health

"Ruangan poliklinik gigi dan mulut yang kecil membuat tidak nyaman karena ruang tunggu pasien dekat dengan ruang pemeriksaan dan kurang privasi karena hanya di batasi oleh tirai tipis”.

Hal serupa juga di sampaikan oleh informan 6 layanan In Health

"Ruangan poliklinik gigi dan mulut yang kecil membuat tidak nyaman karena ruang tunggu pasien dekat dengan ruang pemeriksaan dan kurang privasi karena hanya di batasi oleh tirai tipis”.

Tampilan fisik dianggap elemen yang sangat penting bagi pasien dikarenakan sebuah elemen yang dapat dirasakan langsung oleh pasien. Semakin baik persepsi pasien terhadap tampilan fisik maka kepuasan pasien akan semakin tinggi begitu juga sebaliknya.

Hasil penelitian ini sesuai dengan penelitian yang dilakukan oleh Rifadarajad,dkk [16] yang menjelaskan bahwa sebagian besar menyatakan tidak setuju bahwa ruang kesehatan gigi dan mulut memiliki gedung yang baik dan nyaman, karena ruangannya tidak terlalu besar, kursinya juga menggunakan kursi standar.

Berdasarkan hasil tersebut dapat disimpulkan bahwa faktor tangible (bukti fisik) berhubungan dengan tingkat kepuasan pasien, dimana mereka berasumsi bahwa ruang pemeriksaan dan ruang tunggu yang bersih, rapi dan nyaman, memiliki alat medis yang cukup lengkap, penampilan dokter dan perawat bersih serta semakin baik bukti langsung penyedia pelayanan kesehatan yang dilihat oleh pasien atau 
Journal of Healthcare Technology and Medicine Vol. 6 No. 2 Oktober 2020

Universitas Ubudiyah Indonesia

e-ISSN : 2615-109X

pelanggan maka akan semakin baik pula tingkat kepuasan yang dirasakan oleh pasien. Hal ini dapat dilakukan oleh petugas kesehatan untuk dapat menunjang mutu pelayanan kesehatan dalam meningkatkan jumlah kunjungan pasien ke rumah sakit.

Sarana prasarana memiliki kegunaan untuk mendukung dalam melakukan upaya pelayanan kesehatan terhadap pasien di rumah sakit, alat kesehatan yang disediakan oleh rumah sakit sebagai sarana pendukung penyelenggara pelayanan kesehatan. Sarana dan prasarana yang dioperasikan dan digunakan di rumah sakit baik peralatan medis dan nonmedis harus memenuhi standar pelayanan mutu, keamanan, keselamatan dan digunakan sesuai dengan indikasi medis pasien yang pengoperasian dan pemeliharaannya dilakukan oleh petugas yang mempunyai kompetensi dibidangnya [17].

Hasil wawancara tersebut sesuai dengan penelitian yang dilakukan oleh Widyastuti [18] rata-rata responden mengatakan sangat setuju dengan pernyataan yaitu ruang praktik dokter gigi bersih karena ruangan menggunakan Air Conditioner (AC), ruangan yang tertata rapi, bersih dan tidak berbau. Pernyataan yang ada di dimensi bukti fisik yaitu dokter gigi menjaga kerapian dan kebersihan rata-rata responden memilih jawaban sangat setuju dengan pernyataan tersebut karena dokter gigi serta perawatnya memakai pakaian yang rapi dan sopan.

Peralatan yang tidak lengkap mengakibatkan berkurangnya mutu pelayanan kesehatan yang berdampak pada kunjungan. Hal ini mungkin dapat di tangulangi dengan adanya pendekatan dokter gigi sebagai pemberi pelayanan kesehatan dan dengan menyediakan peralatan yang lengkap dan baik untuk digunakan, sehingga tidak mengurangi tingkat kepuasan pasien dan pasien tetap melakukan kunjungan.

\section{KESIMPULAN}

Dari hasil penelitian yang dilakukan maka di peroleh kesimpulan bahwa informan tidak puas terhadap dimensi kehandalan, daya tanggap, empati dan tampilan fisik di karenakan antrian masalah antrian, pelayanan dokter yang terburu-buru, petugas kesehatan tidak memberikan penjelasan dan pemahaman dengan baik, dokter kurang memberikan perhatiannya ketika memberikan pelayanan, ruangan yang kecil, berisik dan kurang terjaga privasinya. Sedangkan informan yang puas hanya pada variabel jaminan dikarenakan pelayanan yang di dapatkan sangat baik dan dokter mampu meyakinkan kesembuhan pasien, memberikan rasa aman, ramah, sopan dan lembut.

\section{SARAN}

Bagi Rumah Sakit Umum Daerah Tgk Chik Ditiro Sigli berdasarkan dimensi kehandalan sebaiknya manajemen rumah sakit melakukan evaluasi terhadap proses penerimaan pendaftaran pasien agar tidak terjadi antrian pasien yang lama. Peneliti selanjutnya perlu dilakukan penelitian lebih lanjut terhadap aspek 
Journal of Healthcare Technology and Medicine Vol. 6 No. 2 Oktober 2020

Universitas Ubudiyah Indonesia

e-ISSN : 2615-109X

interaksi dan reaktivitas pada pelayanan kesehatan gigi dan mulut serta dapat memberikan kontribusi dalam pengembangan ilmu pengetahuan yang telah ada terutama mengenai kepuasan pasien terhadap pelayanan kesehatan gigi. Bagi Tenaga Kesehatan sebaiknya melakukan pelatihan komunikasi terhadap petugas kesehatan di Rumah Sakit secara rutin untuk meningkatkan interaksi yaitu komunikasi dua arah antara petugas kesehatan dengan pasien, dan berguna untuk meningkatkan keandalan dan ketanggapan petugas kesehatan ketika memberikan perawatan. Bagi Institusi Kesehatan Helvetia diharapkan dapat menjadi bahan pustaka dan referensi serta informasi bagi Institut Kesehatan Helvetia terkait dengan permasalahan yang ada di rumah sakit terhadap kepuasan pelayanan kesehatan gigi dan mulut terhadap pasien.

\section{DAFTAR PUSTAKA}

1. Undang-Undang RI No 36 Tahun 2009 Tentang Kesehatan

2. Hobdell, M. Petersen, P.E. Clarkson, J. Johnson, N. Global goals for oral health 2020. International Dental Journal; 2003,53, 285-28.

3. Kemenkes, RI. Pedoman pelayanan kesehatan gigi dan mulut Indonesia sehat. Jakarta: Kemenkes RI; 2014.

4. Maharani, D.A., Rahardjo, Anton. Mother's dental health behaviors and mother-child's dental caries experiences: Indonesia: Study of A Suburb Area in Indonesia Makara Kesehatan; 2012.

5. Ghofur, A. Buku Pintar Kesehatan Gigi dan Mulut. Yogyakarta: Penerbit Mitra Buku; 2012

6. Idawati, Penerapan Standar Rumah Sakit Umum Daerah, Jurnal Serambi, vol. 7, no. 3, pp. 205-215, 2019.

7. Supriyatno B., Konsil Kedokteran Indonesia. Standar Komptensi Dokter Gigi Indonesia. Jakarta: Konsil Kedokteran Indonesia; 2015

8. Youlanda.M. Kualitas Pelayanan Kesehatan Poli Gigi Rumah Sakit Kota Palembang. MBIA. Vol.17 (3); Desember.2018. ISSN 2086-5090

9. Handayani. S. Tingkat Kepuasan Pasien Terhadap Pelayanan Kesehatan Di Puskesmas Baturetno. Profesi. Vol 14 (1): September 2016

10. Meilana.D. Pengaruh Kualitas Pelayanan Pada Kepuasan Pasien Di Puskesmas Rawat Inap Tanjung Mas Makmur Kabupaten Mesuji Provinsi Lampung. Universitas Lampung Bandar lampung.2017

11 Nisa.K. Harahap.J.Zein.U. Analisis Kepuasan Pasien Dan Kualitas Pelayanan Kesehatan Di Rumah Sakit Gigi Dan Mulut Pendidikan Universitas Sumatera Utara. Scientific Medical Journal. Vol.2(1);2020

12. Embrik Inna Sholihati. Persepsi kepuasan pasien pada kualitas pelayanan di Rumah Sakit Gigi dan Mulut Universitas Muhammadiyah Yogyakarta. Tesis. Magister Manajemen Rumah Sakit Universitas Muhammadiyah Yogyakarta; 2012

13. Aulia R, Adhani R, Taufiqurrahman I, Hatta I. (2017). Pengaruh Kualitas Pelayanan Kesehatan Gigi dan Mulut Terhadap Kepuasan Pasien BPJS di Layanan Primer Banjarmasin. Dentino. 2(1):95-100.

14. Fahdillah.N.A. Hubungan Mutu Pelayanan Kesehatan Gigi Dan Mulut Melalui Tingkat Kepuasan Pasien Di RSUD DR. Sobirin Kota Lubuklinggau. Skripsi. Fakultas Kedokteran Gigi Universitas Sriwijaya.2018.

15. Ladytama.S. Sugiarto.J. Sudiro. Pengaruh Kualitas Pelayanan Kesehatan Gigi Dan Mulut Terhadap Kepuasan Pasien Di Poliklinik Gigi RSI Sultan Agung Semarang. Jurnal Manajemen Kesehatan Indonesia. Vol. 6 (2);Agustus.2018.

16. Rifadarajad S, Sarita B, Balaka MY. (2017). Faktor-Faktor Yang Berpengaruh Pada Loyalitas Pengguna 
Journal of Healthcare Technology and Medicine Vol. 6 No. 2 Oktober 2020

Universitas Ubudiyah Indonesia

e-ISSN : 2615-109X

Rawat Inap Rumah Sakit Umum Daerah Kabupaten Buton. Jurnal Progam Ekonomi Pembangunan. 1(2):56-64.

17. Nurliawati, A. D. Fitriani, Jamaluddin, and Idawati, Analisis Pelaksanaan Clinical Pathway Di Rumah Sakit Umum, J. Biol. Educ., vol. 7, no. 2, pp. 151-166, 2019.

18. Widyastuti.N.H. Handayani.I.T. Pengaruh Kualitas Pelayanan Konservasi Gigi Terhadap Kepuasan Pasien BPJS Di Fasilitas Kesehatan Tingkat Pertama Kota Surakarta (Kajian Di Puskesmas Gajahan). University Research Colloquium. Asiyiyah Yogyakarta.2020. 